\title{
Okul Öncesi Öğrencilerinin Mekân AlgıSı ve Yön Becerilerine Yönelik Öğretmen Görüşlerinin İncelenmesi
}

\author{
Yavuz Değirmenci", Ayhan Bulut ${ }^{* *}$, Memet Kuzey ${ }^{* * *}$
}

Makale Geliş Tarihi: 17/03/2020

Makale Kabul Tarihi: 23/06/2020

DOI: $10.35675 /$ befdergi.069069

$\ddot{O} z$

Okul öncesi ĕgitim, bireylere eğitim ve ögretimle ilgili beceri, dĕger, uygulama ve ekinliklerin planlı bir şekilde kazandırılmaya başlandığı ilk dönem olarak ifade edilebilir. Bu nedenle önemi her geçen gün farkl platformlarda dile getirilen okul öncesi eğimle ilgili çalışmalar da giderek artmaktadır. Bu araştırmanın amacı, okul öncesi dönemde ögrrenim gören ögrencilerin mekân algisı ve yön becerilerine yönelik öğretmen görüşlerinin incelenmesidir. Nitel araştırma yöntemlerinden biri olan durum deseniyle tasarlanan bu araştırma 2019-2020 eğitim öğretim döneminde hâlihazırda görev yapan toplam 26 okul öncesi ögretmeni ile yürütülmüşı̈̈r. Araştırmada elde edilen veriler yarı yapılandırılmış görüşme formu ile toplanmış ve bu veriler betimsel analizine tabi tutularak değerlendirilmiştir. Araştırmada elde edilen bulgulara göre, mekân algısı ve yön becerilerine yönelik okul öncesi ögretmenleri çeşitli kavram ve beceriler kazandırdıkları, bunları kazandırırken farklı yöntem, teknik, uygulama ve etkinlikler kullandıkları, bazı kavramların öğretilmesinde çeşitli nedenlerden dolayı zorluklar yaşadıkları ve son olarak bunlara ilişkin bazı çözüm önerileri sundukları görülmüştür.

Anahtar Kelimeler: Mekân, mekân algısı, okul öncesi eğitim, yön kavramı

\section{Investigation of Teachers' Opinions about Space Perception and Direction Skills of Preschool Students}

Abstract

Preschool education can be expressed as the first period in which individuals started to acquire skills, values, practices and activities related to education and training in a planned way. For this reason, the studies on pre-school education, which are mentioned on different platforms, are increasing day by day. The aim of this study is to examine the teachers' views on

\footnotetext{
* Bayburt Üniversitesi, Bayburt Eğitim Fakültesi, Türkçe ve Sosyal Bilimler Eğitimi Bölümü, Sosyal Bilgiler Eğitimi Anabilim Dalı, Bayburt, Türkiye, degirmenci67@ gmail.com, ORCID: 0000-0003-3417-1775 (iD

** Bayburt Üniversitesi, Bayburt Eğitim Fakültesi, Temel Eğitim Bölümü, Okul Öncesi Eğitimi Anabilim Dalı, Bayburt, Türkiye, ayhanbulut44@hotmail.com, ORCID: 0000-0001-64828032 (D)

*** Bayburt Üniversitesi, Bayburt Eğitim Fakültesi, Türkçe ve Sosyal Bilimler Eğitimi Bölümü, Sosyal Bilgiler Eğitimi Anabilim Dalı, Bayburt, Türkiye, memetkuzey@bayburt.edu.tr. ORCID: 0000-0002-9866-8134
}

Kaynak Gösterme: Değirmenci, Y., Bulut, A., \& Kuzey, M. (2021). Okul öncesi öğrencilerinin mekân algısı ve yön becerilerine yönelik öğretmen görüşlerinin incelenmesi. Bayburt Eğitim Fakültesi Dergisi, 16(31), 21-38. https://doi.org/10.35675/befdergi.069069. 
the perceptions of space and direction skills of students studying in pre-school period. This research was designed according to the case study, which is one of the qualitative research methods. The study was conducted with 26 pre-school teachers who are currently working in the 2019-2020 academic year. The data obtained in the study were collected through a semistructured interview form and these data were analyzed by descriptive analysis. According to the findings obtained in the research. It has been observed that preschool teachers provide students with a variety of concepts and skills for their perception of space and direction skills. In the meantime they use different methods, techniques, practices and activities. But they have difficulties in teaching some concepts and finally they offer some solutions for them.

Keywords: Direction concept, perception of place, place, preschool education

\section{Giriş}

Okul öncesi dönem çocuğun ilk altı yaşını kapsar ve çocuğun hayat boyu gelişimini yapılandırdığı bir süreci ifade eder. Beyin gelişiminin ve sinaptik bağlantıların kurulma oranının en yoğun olduğu ve hızlı yaşandığı dönem, çocuğun bilişsel, motor ve duyuşsal gelişimi için güçlü bir zemin oluşturur (MEB, 2013). Okul öncesi dönemde çocuklar zihin gelişiminin üçte ikisini, sinir sistemi gelişimin yaklaşık olarak beşte dördünü tamamlar. Bu nedenle ilk beş yıl içinde alınan eğitimin niteliği çocuğun var olan potansiyel gücünü gerçekleştirme düzeyini doğrudan etkiler (Selçuk, 2005; Ayvaz, 2007).

Etkin ve kalıcı eğitim 0-6 yaş aralığında gerçekleşmektedir. Bu yaş dönemi çocuğun en verimli yıllarıdır. Başka bir ifadeyle çocuğun hayata hazırlanmasında ve temel yetenekler geliştiği gelişmesinde kritik süreçtir. Bu süreçte birey için gerekli olabilecek öğrenmeler gerçekleşmez ise bu öğrenmeler hayatın diğer dönemlerinde daha zor gerçekleşir. Kısaca bu evrede öğrenilen her şey çocuğun hayatına yön verdiği için altın çağ olarak görülmektedir (Akkuş, 2019). Dolayısıyla bireylerin sürekli iç içe oldukları ve yaşamlarında sıklıkla kullanabilecekleri mekân, yer ve yön gibi kavramlar bu dönemdeki bireylere öğretilmesi gereken kazanımlar arasında yer alır. Çünkü çocuklar, dünyaya geldikleri andan itibaren bir mekân içerisinde kendilerini bulmaktadırlar. Bu durum çocuğun fiziksel, sosyal, duygusal ve toplumsal gelişimine yön verebilmektedir (Anıktar, 2008). Bu dönem çocuğun gelişim özellikleri, alınan eğitimin niteliği ve mekânın çocuk üzerindeki etkisi dikkate alındığında mekân ve yön ögretiminin nedenli önemli olduğu da görülmektedir.

Okul öncesi dönemde çocuklar, kendilerini güven duygusuyla saran mekânı keşfetmeye öğrenmeye karşı doğal bir istekleri olur. Bu istekleri merak, araştırma ve aktif katılımlı bir süreçten oluşur. Bu bağlamda mekânı ve sembolik temsilleri anlamak gibi davranışlar ortaya koyarak bilgi sahibi olmaya çalışırlar (Öztürk, Giren, Yıldırım \& Şimşek, 2015). Örneğin çocuklar günlük hayatta bulundukları ev içerisinde bir odadan diğer bir odaya gitme istekleri bu merakın ve öğrenmenin bir algısal ve eylemsel yansımasıdır. Böylece mekânı tanıma süreç olarak algıya ve mekânı ilişkilendirme de yön bulmaya dönüşür. Çünkü ister kapalı ister açık bir 
mekânda bulunsun öncelikle sahip olmak isteyeceği duygu nerede olduğunu bilmektir (Akgün, 2011).

Yer, bulunulan yer, ev, yurt, gök ve uzay (Türk Dil Kurumu [TDK], 2011) gibi farklı şekillerde tanımlanan mekân kavramının çocuklarda gelişmesinde çocukların eylemleri, çevreleri ile olan etkileşimleri önemlidir (Ayvaz, 2007). Çocuğun mekân içerisindeki hareket kabiliyeti mekân kavramının sınırlarını da genişletmektedir. Dolayısıyla çocukların mekân ile ilişki kurmaları ve bilgi aktarımı duyum ve algı yoluyla gerçekleşmekte (Ayvaz, 2007) ve mekânı görsel olarak algılamaktadırlar (Anıktar, 2008). Bu bağlamda çocuğun mekândan yararlanabilmesi mekânı tanımasına ve anlamasına bağlıdır. Çocuk mekânı dokunarak, fiziksel aktivitelerde bulunarak bedeni ile algılamaktadır (İncekara, 2018). Çocuğun mekândan aldığ1 bilgilere uygun olarak hareket etmesine yardım edecek şekilde yorumlayıp değerlendirmesi yani mekânla iletişim kurması mekânsal algı kavramını ortaya çıkartmaktadır (Hasgül, 2011). Mekân algısı ise çocuğun mekân içerisinde deneyimler kazanması ve bu doğrultuda mekânı hatırlamasıdır (Anıktar, 2008). Çocuğun mekân içerisinde hareket edebilmesi algılamayı, mekânı algılayabilmesi içinde hareket etmesi gereklidir. Bu bağlamda algı çocuğun davranışlarının şekillenmesinde önemli bir rol oynarken, beden konumlarına göre nesnelerin çevredeki yönünün algılanması da yön becerilerini ortaya çıkarır. Sonuç olarak yön algısının gelişimi hem deneyime hem de olgunlaşmaya bağlı olarak gelişir (Aslan, 2017). Nitekim yapılan bazı çalışmalarda (Plester vd. 2002; Huttenlocker, Newcombe \& Vasilyeva, 1999; Blades, Sowden, \& Spencer, 1996) okul öncesi dönemde çocukların mekânsal bilgileri ve ilişkileri çeşitli şekillerde anlayabildikleri ve yorumlayabildikleri ifade edilmiştir. Ayrıca bu dönemde basit düzeyde harita çalışmaları, yer, yön, konum ve mesafe sözcüklerine yer verme ve çeşitli etkinliklerin planlanması çocuklarda mekânsal düşünme becerilerini de geliştirecektir (Soydan, 2014).

Okul öncesi dönemde alınan eğitimin niteliğinin bu kadar önemli olması mekân ve yön bilgisinin de bu dönemde verilmesini gerekli kılmaktadır. Nitekim bu amaçla okul öncesi eğitim programı ve etkinlik kitabı incelendiğinde, mekân ve yön öğretimi okul öncesi programında yer aldığı görülmektedir. Program ve etkinlik kitabında; 48 60 aylık çocukların mekân ve yön kavramlarıyla ilgili sadece bilişsel gelişime yönelik kazanımlara ve etkinliklere yer verildiği görülmektedir. Bu dönemde bilişsel gelişim süreciyle ilgili olarak da, mekânda konum ile ilgili yönergeleri uygulamaya yönelik çalışmalara yer almaktadır. Bu yönerge kapsamında nesnenin mekândaki konumunu söyleme, nesneleri yönerge kapsamında istenilen yere yerleştirme çalışmaları yapar. Mekânda konumla ilgili yönerge kapsamında harita ve krokiyi kullanma çalışmalarına yönelik kazanım çalışmalarına yer verilmektedir. Bununla birlikte 60-72 aylık üstün yetenekli çocuklara fen etkinlikleri kapsamında bireysel veya grup çalışmaları kapsamında kroki çizim etkinlikleri yaptırılabilir. Ayrıca bu yönerge kapsamında çocuklara yön, mekânda konumla ilgili olarak; ön- arka, yukarı-aşağı, ileri- geri, sağsol, önünde- arkasında, alt- üst- orta, altında-artasında-üstünde, arasında, yanında, yukarıda- aşağıda, iç-dış, içinde-dışında, içeri-dışarı, uzak-yakın, alçak-yüksek, 
sağında- solunda (MEB, 2013) gibi kavramların öğretilmesi amaçlanmıştır. Dolayısıyla bu dönemde bireylere verilecek mekân ve yön bilgisi çocuğun mekân ve yön hakkında farkındalık düzeyini artıracaktır. Bu kapsamda ilgili literatür incelendiğinde (Demirkaya, Çetin \& Tokcan, 2004; Ayvaz, 2007; Anıktar, 2008; Uçar, 2013; Kurt, 2016; Aslan, 2017; Yaylacı \& Aksoy, 2017; Kuzey \& Değirmenci, 2019; Aydınözü, Demirbaş \& Demir, 2019; Şahin, 2019) birçok araştırmacı tarafından mekan algısı ve yön kavramlarına yönelik çeşitli çalışmaların yer aldığı, ancak okul öncesi dönemdeki bireylere mekan algısı ve yer, yön becerilerine yönelik hangi kavramların verildiği, bu kavramların çocuklara nasıl kazandırıldığı ile ilgili çalışmaların sınırlı olduğu görülmüştür. Dolayısıyla sahadan öğretmen görüşü alarak çocuklara bu kavram ve becerilerin nasıl kazandırıldığı, ne tür yöntem, teknik, uygulama veya etkinliklerin kullanıldığı, süreçte yaşanan zorluklar ve varsa katılımcıların çözüm önerilerinin neler olduğunun ortaya konulması bu araştırmanın en önemli boyutunu oluşturmakta ve ilgili literatüre katkı sağlayacağı beklenmektedir.

\section{Yöntem}

\section{Araştırma Modeli}

Okul öncesi dönemde öğrencilerin mekân algıları ve yön becerilerine yönelik olarak okul öncesi dönemde görev yapan öğretmenlerin görüşlerinin incelendiği bu çalışmada nitel yaklaşımlarından biri olan durum deseni (case study) kullanılmıştır. Nitel araştırmalar, doğal ortamda algıların veya birden fazla gerçek yaşam olaylarının gerçekçi ve bütüncül bir bakış açısıyla ortaya konulmaya çalışıldığı araştırmalardır. $\mathrm{Bu}$ yaklaşımda ve birçok sosyal bilim alanında yaygın olarak kullanılan desenlerden biri de araştırmalarda bilimsel sorulara cevap aramada ayırt edici bir yaklaşım olarak görülen durum desenidir (Yin, 2018; McMillan, 2015; Merriam, 2013; Yıldırım \& Şimşek, 2011). Bu desen özellikle öğrenme-öğretme ortam ve süreçlerinin karmaşıklığını anlama, ortaya koyduğu sonuçlarla eğitim kuram ve uygulamalarını etkileme potansiyelinin yüksek olması nedeniyle son yıllarda birçok eğitim araştırmalarında tercih edildiği görülmektedir (Uçan, 2019). Dolayısıyla araştırmacının gerçek yaşam içerisinde çoklu bilgi kaynakları (görüşme, gözlem, doküman ve rapor gibi) aracılığıyla detaylı ve derinlemesine bilgi toplandığı bir yaklaşım (Creswell, 2016) olarak ifade edilir. Çalışmanın verilerinin toplanmasında araştırmacılar tüm etik kurallara uymuştur.

\section{Çalışma Grubu}

Bu araştırma, 2019-2020 eğitim öğretim yılında Türkiye’de bir il merkezinde hâlihazırda görev yapmakta olan ve amaçlı örnekleme metoduna uygun olarak seçilen 26 okul öncesi öğretmenleri ile yürütülmüştür. Araştırmada yer alan katılımcılara ait veriler Tablo 1'de verilmiştir. 
Tablo 1.

Çalıșma Grubu

\begin{tabular}{llll}
\hline Hizmet Y1l1 & Kadın & Erkek & Toplam \\
\hline $1-5$ yıl arası & 6 & - & 6 \\
6-9 yıl aras1 & 4 & - & 4 \\
10-15 y1l aras & 13 & - & 13 \\
15 ve üzeri & 3 & - & 3 \\
\hline Toplam & 26 & - & 26 \\
\hline
\end{tabular}

Tablo 1 incelendiğinde, araştırmada yer alan katılımcıların farklı öğretmenlik deneyimine sahip oldukları görülmektedir. Çalışma grubunun tamamını kadın öğretmenler oluştururken, 6 y1l ve daha fazla öğretmenlik deneyimine sahip, yani nispeten daha deneyimli kabul edilebilecek katılımcı oranının (\% 70 ve üzeri) yüksek olduğu dikkat çekmektedir. Bu durumun, verilerin çeşitliliği ve zenginliğini artırmada olumlu bir etki oluşturacağı savunulabilir.

\section{Veri Toplama Aracı}

Araştırmada, farklı öğretmenlik deneyimine sahip okul öncesi öğretmenlerinin görüşlerine göre okul öncesi dönemdeki bireylerin mekân algıları ve yön becerilerinin neler olduğu, bunlara yönelik hangi kavram veya becerilerin kazandırıldığı, bu becerileri kazandırırken ne tür yöntem, tekniklerin veya uygulamaların kullanıldığ1, mekân algısı ve yönlerle ilgili öğretiminde zorluk yaşanan kavramlar ve son olarak varsa çözüm önerilerinin neler olabileceği ile ilgili görüş ve düşünceleri nitel araştırmalarda yaygın olarak kullanılan görüşme tekniği kullanılarak incelenmiştir (Brinkmann, 2013). Elde edilen veriler ise gerekli uzman görüşü de alınarak araştırmacılar tarafından geliştirilen yarı yapılandırılmış görüşme formu ile toplanmıştır. Nitel araştırmalarda kullanılan görüşmeler, genellikle belirli bir konu hakkında katılımcıların, görüş, düşünce ve fikirlerinin alınmaya çalışıldığı birkaç açık uçlu soruyu içeren süreci ifade eder (Creswell, 2017). Bu tekniğin amacı doğrudan gözlem yapılamayan durumlarda katılımcıların bakış açılarının derinlemesine incelemeye çalışmaktır (Patton, 2002). Bu amaç doğrultusunda her bir öğretmenle ortalama 35-40 dakika süren görüşmeler yapılmış ve araştırma sorularına cevaplar aranmaya çalışılmıştır.

\section{Verilerin Analizi ve Değerlendirilmesi}

Araştırmada incelenen durumla ilgili elde edilen veriler betimsel analizine tapi tutularak değerlendirilmiştir. Betimsel analiz, daha önceden belirlenen araştırma sorularının ortaya koymuş olduğu temalara göre düzenlenebilir veya veriler görüşme sürecinde kullanılan sorular ve boyutlar dikkate alınarak da sunulabilir. Bu analizde bireylerin görüşlerini çarpıcı bir şekilde yansıtmak amacıyla doğrudan alıntılara da yer verilir. Burada amaç elde edilen bulguları düzenlenmiş ve yorumlanmış bir şekilde okuyucuya sunmaktır (Yıldırım \& Şimşek, 2011). Buradan hareketle araştırmada 
ulaşılan veriler çeşitli tema ve kategoriler altında toplanmış ve açık bir şekilde tablolarda sunularak yorumlanmıştır. Katılımcıların görüş, düşünce ve fikirlerini yansıtmak amacıyla da sik sik doğrudan alıntılara yer verilmiştir. Araştırmanın gizliliğine dikkat edilerek katılımcılara ait bilgilere yer verilmemiş onun yerine her bir katılımcıyı temsil eden "öğretmen 1; öğretmen 2 (Ö1; Ö2) şeklinde kodlamalar kullanılmıştır. Araştırmanın geçerliği sağlamak için doğruluk ve inandırıcılık önemlidir. Bu nedenle araştırma sürecine ilişkin bilgiler paylaşılarak verilere ne şekilde ulaşıldığ verilmesi geçerlik adına önemli görülmektedir (Yıldırım \& Şimşek, 2011). Araştırmanın güvenirliği için ise gerekli uzman görüşüne başvurulmuştur. Elde edilen veriler 1şı̆̆ında ulaşılan tema ve kategoriler faklı iki alan uzmanına verilmiş ve uzman görüşleri sonrasında verilerin güvenirliğini sağlamak için Miles \& Huberman (1994) tarafından geliştirilen ve nitel çalışmalarda sıklıkla kullanılan [Görüş birliği / (Görüş birliği + Görüş ayrılığı) x 100] formülü esas alınarak araştırmacı ve uzman görüşü arasındaki uyuşma oranına bakılmış ve bu oranın \% 90'ın üzerinde olduğu tespit edilmiştir. Daha sonra veriler tablolarda frekans (f) ve yüzde (\%) şeklinde sunularak yorumlanmıştır.

\section{Bulgular ve Yorum}

Araştırmanın bu bölümünde okul öncesi öğretmenleriyle yapılan görüşme sonrasında ulaşılan bulgular araştırma soruları da dikkate alınarak sırasıyla verilmiştir. Tablo 2'de öğretmenlerin okul öncesi dönemde mekân algısı ve yön becerisine yönelik öğrencilere kazandırmaya çalıştıkları kavramlar ve becerilere ilişkin görüşleri yer almaktadır.

Tablo 2.

Öğretmenlerin Okul Öncesi Dönemde Mekân Algısı Ve Yön Becerisine Yönelik Öğrencilere Kazandırmaya Çalıştıkları Kavramlar

\begin{tabular}{lcc}
\hline Kavramlar & Frekans (f) & Yüzde (\%) \\
\hline Sağ-sol kavramları & 23 & 15,13 \\
Alt-üst kavramları & 22 & 14,47 \\
Ön-arka kavramları & 21 & 13,81 \\
İleri-geri kavramları & 16 & 10,52 \\
İçinde-dışında kavramları & 16 & 10,52 \\
Aşağı-yukarı kavramları & 14 & 9,21 \\
Uzak-yakın kavramları & 13 & 8,55 \\
Başında, ortasında ve sonunda kavramları & 9 & 5,92 \\
Yanında-arkasında kavramları & 8 & 5,26 \\
Alçak-yüksek kavramları & 8 & 5,26 \\
Derin-sığ kavramları & 1 & 0,65 \\
Geniş-dar kavramları & 1 & 0,65 \\
\hline Toplam & $\mathbf{1 5 2}$ & $\mathbf{1 0 0}$ \\
\hline
\end{tabular}


Tablo 2 incelendiğinde, katılımcılar okul öncesi dönemde öğrencilere mekân algısı ve yön becerilerine yönelik çeşitlik kavramları kazandırmaya çalıştıkları tespit edilmiştir. Tablo 2'ye göre bu kavramların başında sırasıyla sağ ve sol (\% 15,13), alt ve üst $(\% 14,47)$, ön ve arka $(\% 13,81)$, ileri ve geri $(\% 10,52)$, içinde ve dişında $(\%$ 10,52) kavramları gelmektedir. Bununla birlikte kazandırılmaya çalışılan diğer kavramlar ise aşağl-yukarı (\% 9,21), uzak-yakın (\% 8,55), Başında, ortasında ve sonunda (\% 5,92), Yanında-arkasında (\% 5,26), Alçak-yüksek (\% 5,26), Derin-sı̆̆ (\% $0,65)$ ve son olarak Geniş-dar $(\%$,65) kavramlarıdır. Tablo 3 'te ise incelenen kavramlara yönelik kazandırılmaya çalışılan beceriler yer almaktadır.

Tablo 3.

Öğretmenlerin Okul Öncesi Dönemde Mekân Alglsı Ve Yön Kavramına Yönelik Öğrencilere Kazandırmaya Çalıştıkları Beceriler

\begin{tabular}{lcc}
\hline & Frekans (f) & Yüzde (\%) \\
\hline Yönergelere uygun hareket edebilme & 11 & 36,66 \\
Nesneleri konumlarına göre yerleştirme & 6 & 20,00 \\
Mekânda konum alabilme & 4 & 13,33 \\
Bir nesnenin bulunduğu konumu söyleyebilme & 4 & 13,33 \\
Yön kavramını öğrenebilme & 4 & 13,33 \\
Nesneleri sıralayabilme & 3 & 10,00 \\
Hedefe atma ve yakalayabilme & 1 & 3,33 \\
Sağ ve solu gösterebilme & 1 & 3,33 \\
Sağa-sola dönme ve yürüyebilme & 1 & 3,33 \\
Harita ve kroki kullanabilme & 1 & 3,33 \\
Mekânda ileri ve geri yürüyebilme & 1 & 3,33 \\
Yönergelere uygun nesneleri bulabilme & 1 & 3,33 \\
El ve göz koordinasyonunu sağlayabilme & 1 & 3,33 \\
Adres tarif edebilme & 1 & 3,33 \\
Mekânsal ilişkileri kavrayabilme & 1 & 3,33 \\
\hline Toplam & $\mathbf{3 0}$ & $\mathbf{1 0 0}$ \\
\hline
\end{tabular}

Tablo 3 incelendiğinde, katılımcılar okul öncesi dönemde öğrencilere mekân algısı ve yer-yön kavramına yönelik kazandırmaya çalıştıkları çeşitli beceriler yer almaktadır. Bu beceriler arasında yönergelere uygun hareket edebilme $(\% 36,66)$ ve nesneleri konumlarına göre yerleştirme (\% 20,00) becerileri ilk sıralarda geldiği dikkat çekmektedir. Sırasıyla kazandırılmaya çalışılan diğer beceriler ise mekânda konum alabilme (\% 13,33), bir nesnenin bulunduğu konumu söyleyebilme (\% 13,33), yön kavramını ögrenebilme (\% 13,33), nesneleri stralayabilme (\% 10,00), hedefe atma ve yakalayabilme (\% 3,33), să̆ ve solu gösterebilme $(\% 3,33)$, săga-sola dönme ve yürüyebilme $(\% 3,33)$, harita ve kroki kullanabilme (\% 3,33), mekânda ileri ve geri yürüyebilme (\% 3,33), yönergelere uygun nesneleri bulabilme (\% 3,33), el ve göz koordinasyonunu sağlayabilme $(\% 3,33)$, adres tarif edebilme $(\% 3,33)$, ve son olarak da mekânsal ilişkileri kavrayabilme (\% 3,33) becerileri yer almaktadır. Tablo 4'te 
öğretmenlerin incelenen kavram ve becerileri kazandırmada kullanmış oldukları uygulama, yöntem, teknik ve etkinliklere yer verilmiştir.

Tablo 4.

Öğretmenlerin İncelenen Kavram Ve Becerileri Kazandırmada Kullanmış Oldukları Yöntem, Teknik Uygulama Ve Etkinlikler

\begin{tabular}{lccccc}
\hline $\begin{array}{l}\text { Yöntem ve } \\
\text { teknikler }\end{array}$ & $\begin{array}{c}\text { Frekans } \\
(\mathbf{f})\end{array}$ & $\begin{array}{c}\text { Yüzde } \\
(\boldsymbol{\%})\end{array}$ & Uygulama ve etkinlikler & $\begin{array}{c}\text { Frekans } \\
(\mathbf{f})\end{array}$ & $\begin{array}{c}\text { Yüzde } \\
(\boldsymbol{\%})\end{array}$ \\
\hline Gösterip & 11 & 22,91 & Oyun & 26 & 45,61 \\
yaptırma & & & & & \\
Drama & 10 & 20,83 & Okuma-yazma çalışmaları & 10 & 17,54 \\
Soru cevap & 7 & 14,58 & Kavram kartları & 4 & 7,01 \\
Anlatım & 5 & 10,41 & Hikayeleştirme etkinliği & 3 & 5,26 \\
Yaparak- & 4 & 8,33 & Komut (yönlendirme) & 3 & 5,26 \\
yaşayarak & & etkinliği & & 3,50 \\
İstasyon & 3 & 6,25 & Sanat etkinliği & 2 & 3,50 \\
Beyin firtınası & 3 & 6,25 & Sesli çalışmalar & 2 & 1,75 \\
Örnek olay & 1 & 2,08 & Labirent etkinliği & 1 & 1,75 \\
Tartışma & 1 & 2,08 & Resimli kartlar & 1 & 1,75 \\
Rol yapma & 1 & 2,08 & Hareket etkinliği & 1 & 1,75 \\
Benzetim & 1 & 2,08 & Deneme-yanılma & 1 & 1,75 \\
Problem çözme & 1 & 2,08 & Çalışma yaprakları & 1 & 1,75 \\
- & - & - & Görsel etkinlikler & 1 & 1,75 \\
\hline- & - & - & Aile destekli çalışmalar & 1 & $\mathbf{1 0 0}$ \\
\hline Toplam & $\mathbf{4 8}$ & $\mathbf{1 0 0}$ & & $\mathbf{5 7}$ & \\
\hline
\end{tabular}

Tablo 4 incelendiğinde, okul öncesi öğretmenleri mekân alg1sı ve yer, yön kavramlarına yönelik becerileri kazandırmada uygulama ve etkinliklere daha fazla yer verdikleri tespit edilmiştir. Bu uygulama ve etkinliklerin başında oyun (\% 45,61), okuma-yazma çalışmaları (\% 17,54) ve kavram kartları (\% 7,01) gelmektedir. Yöntem ve teknikler boyutunda ise öğretmenler daha çok gösterip yaptırma (\% $22,91)$, drama (\% 20,83), soru-cevap (\% 14,58), anlatım $(\% 10,41)$ ve yaparakyaşayarak öğrenme $(8,33)$ farklı yöntem ve teknikleri kullandıkları görülmüştür. Tablo 5'te mekân algısı ve yer, yönlerle ilgili öğretiminde zorluk yaşanan kavramlar ve bunların nedenleri yer almaktadır.

Tablo 5 .

Öğretmenlerin Mekân Algısı Ve Yer-Yönlerle İlgili Öğretiminde Zorluk Yaşadıkları Kavramlar Ve Nedenleri

\begin{tabular}{lcc}
\hline Öğretiminde zorluk yaşanan kavramlar & Frekans (f) & Yüzde (\%) \\
\hline Sağ ve sol kavramları & 20 & 76,92 \\
Ortasında ve arasında kavramları & 2 & 7,69 \\
Derin ve sığ kavramları & 1 & 3,84
\end{tabular}




\begin{tabular}{lcc} 
Siralama kavramı & 1 & 3,84 \\
Yok & 2 & 7,69 \\
\hline Toplam & $\mathbf{2 6}$ & $\mathbf{1 0 0}$ \\
\hline Nedenleri & Frekans (f) & Yüzde (\%) \\
\hline Bazı kavramların soyut oluşu & 13 & 50,00 \\
Bazı kavramların günlük hayatta daha az & 2 & 7,69 \\
kullanılması & 1 & 3,84 \\
Yaşlarının küçük olması & 1 & 3,84 \\
Kavram kargaşası & 1 & 3,84 \\
Bazı kavramların anlaşılmasının zor olması & 8 & 30,76 \\
Neden yok & $\mathbf{2 6}$ & $\mathbf{1 0 0}$ \\
\hline Toplam & & \\
\hline
\end{tabular}

Tablo 5 incelendiğinde, mekân algısı ve yer-yönlerle ilgili bazı kavramların öğretiminde ve kazandırılmasında öğretmenlerin zorluklar yaşadıkları görülmektedir. Katılımcılar, öğretiminde zorluk yaşadıkları kavramları çoğunlukla săg ve sol kavramları $(\%$ 76,92) olarak ifade etmişlerdir. İki katılımcı ise bu soruya ilişkin görüş belirtmemiştir. Öğretiminde zorluk yaşanan kavramların nedenlerine gelindiğinde ise katılımcılara göre bu nedenlerin başında bazı kavramların soyut oluşu (\% 50,00) gelmektedir. Bununla birlikte bazı kavramların günlük hayatta daha az kullanılması (\% 7,69), yaşlarının küçük olması (\% 3,84), kavram kargaşası (\% 3,84) ve bazı kavramların anlaşılmasının zor olması $(\% 3,84)$ diğer nedenler arasında sıralanmıştır. Sekiz katılımcı ise bu konuda neden belirtmemiştir. Öğretiminde zorluk yaşanan kavramların nedenlerine ilişkin bazı katılımcı görüşleri ise şu şekildedir; " $B u$ dönemdeki çocukların yaşlarının küçük olması bazı kavramların ögrretilmesinde zorluk yaşamamıza neden olmaktadır" (Ö1). "Bazl kavramların soyut oluşu çocukların bu kavramları anlamalarını zorlaştırıyor” (Ö8). “Öğrenciler bebeklikten okul öncesi döneme kadar günlük hayatta daha sık karşılaştıkları kavramları daha kolay kavrayabiliyorken, daha az karşılaştıkları kavramları anlamaları zorlaşabiliyor" (Ö4). "Özellikle să̆-sol gibi kavramlar ögrencinin bulunduğu mekâna ve yere göre değiştiği için kavram kargaşasına neden olabiliyor” (Ö19). Tablo 6'da katılımcıların öğretiminde zorluk yaşanan kavramlara ilişkin çözüm önerileri verilmiştir.

Tablo 6.

Öğretmenlerin Öğretiminde Zorluk Yaşanan Kavramlara İlişkin Çözüm Önerileri

\begin{tabular}{lcc}
\hline Çözüm Önerileri & Frekans (f) & Yüzde (\%) \\
\hline $\begin{array}{l}\text { Bireylerin gelişim özelliklerine göre kavramları } \\
\text { somutlaştırmak }\end{array}$ & 7 & 18,91 \\
$\begin{array}{l}\text { Kavramları sürekli hatırlatıcı etkinlikler yapmak } \\
\text { Aile ve ev ortamında pekiştirici etkinlikler }\end{array}$ & 7 & 18,91 \\
yapmak & 4 & 10,81
\end{tabular}


Oyunlara daha fazla yer vermek

\begin{tabular}{cc}
3 & 8,10 \\
3 & 8,10 \\
3 & 8,10 \\
3 & 8,10 \\
3 & 8,10 \\
1 & 2,70 \\
1 & 2,70 \\
1 & 2,70 \\
1 & 2,70 \\
\hline 37 & $\mathbf{1 0 0}$
\end{tabular}

Tablo 6 incelendiğinde, katılımcıların öğretiminde zorluk yaşadıkları kavramlara ilişkin çözüm önerileri yer sıralanmıştır. Bu öneriler incelendiğinde, bireylerin gelişim özelliklerine göre kavramlart somutlaştırmak (\% 18,91), kavramlart sürekli hatırlatıcı etkinlikler yapmak $(\%$ 18,91) ve aile ve ev ortamında pekiştirici etkinlikler yapmak $(\%$ 10,81) gibi öneriler ilk akla gelen çözüm önerileri arasında yer aldığ1 görülmektedir. Bununla birlikte oyunlara daha fazla yer vermek $(\%$ 8,10), etkinlikleri çeşitlendirmek $(\%$ 8,10), günlük yaşamla ilişkilendirmek $(8,10)$, robotik kodlama ve stem etkinlikleri $(\% 8,10)$, yaşantı zenginliği oluşturmak (\% 2,70), akıllı tahta $(\%$ 2,70), örnekleri çeşitlendirmek $(\% 2,70)$ ve son olarak ta eğitici oyunlara daha fazla yer vermek $(\%$ 2,70) diğer çözüm önerileri arasında gelmektedir. Öğretiminde zorluk yaşanan kavramlara ilişkin çözüm önerileriyle ilgili bazı katılımcı görüşleri ise "Çocuğun yaş ve gelişim özelliklerine uygun olarak kavramları daha somutlaştırmak zorlukları aşmada yardımcı olabilir” (Ö7). "Çeşitli oyun ve uygulamalarla kavramları hatırlatıcı etkinlikler yapmak ögrenmeyi destelemektedir” (Ö4). “Aileyi işin içine katarak evde de takviye etkinliklerin yapılması kavramların öğrenilmesinde etkili olabilir" (Ö20). "Çocuklara ne kadar çok yaşantı zenginliği verilirse veya görürse, duyarsa ve yaparsa bir o kadar da etkili ögrenme gerçekleşecektir” (Ö3). "Sınıf içerisinde etkinlikleri çeşitlendirerek oyunlarda sık sık bu kavramlara yer vermek öğrenmeyi olumlu etkiler” (Ö1). "Kavramları günlük yaşamla ilişkilendirmek ögretimi daha kolay hale getiriyor” (Ö16) ş̧eklindedir.

\section{Tartışma, Sonuç ve Öneriler}

Çocuğun hayata gözlerini ilk açtığı andan itibaren içinde yaşadığı mekânı hareket ederek algılaması ve mekânı algılaması içinde hareket etmesi şarttır. Çocuk gelişiminin en kritik ve en önemli dönemi olarak kabul edilen okul öncesi eğitim dönemi çocuğa kendi bedeninin konumuna göre çevresindeki nesnelerin yönünün kavratılmaya çalışıldığ 1 ve çocukta mekânsal alg1 kavramının gelişmesine yönelik bir takım kazanım faaliyetlerinin yürütüldüğü formal eğitim sürecinin ilk basamağını oluşturmaktadır. $\mathrm{Bu}$ araştırma okul öncesi öğrencilerinin mekân algısı ve yön becerilerini daha küçük yaşlardan itibaren çocuklara kazandırmaya çalışan okul öncesi öğretmenleriyle birlikte yürütülmüştür. Bu kapsamda çalışma grubunda yer 
alan okul öncesi öğretmenlerine çocukların mekân ve yön kavramıyla ilgili farkındalıklarını artırmak için ne tür çalışmalar yaptıklarına ilişkin sorular yönlendirilmiştir. Bu sorulara okul öncesi öğretmenlerinin verdiği yanıtlardan yola çıkılarak aşağıda belirtilen sonuçlar elde edilmiştir. Araştırma sürecine katılan okul öncesi öğretmenlerinin tamamının bayan öğretmenlerden oluştuğu belirlenmiştir. Bu sonuçtan hareketle ülkemizde hala okul öncesi öğretmenliği mesleğinin bayanlara yönelik bir meslek olduğu algısının değişmediğini söylemek mümkündür. Nitekim bu sonuç kültürel etkenlerin eğitim üzerindeki yansımalarının ne denli kalıcı izler bıraktığını da gösterdiği ifade edilebilir. İlgili literatür incelendiğinde, Şahin, Korkmaz ve Çoban'ın (2018) ve Yağbasan ve Aksoy'un (2016) çalışma sonuçları bu durumu destekler niteliktedir.

Okul öncesi eğitim döneminde öğretmenler, mekân algısı ve yön becerilerini çocuklara öğretmeye çalışırken en sık olarak; sağ-sol kavramlarını (\% 15,13), alt-üst kavramlarını (\% 14,47), ön-arka kavramlarını (\% 13,81), ileri-geri kavramlarını (\% $10,52)$ ve içinde-dışında kavramlarını $(\%$ 10,52) kullandıklarını ifade etmişlerdir. $\mathrm{Bu}$ araştırma sonucundan da anlaşıldığ1 gibi okul öncesi öğretmenlerinin çocuklara mekân ve yön kavramını öncelikle çocukların içinde bulundukları fiziksel konumlarıyla nesneler arasında bağ kurarak öğretmeye çalıştıkları söylenebilir. Bununla birlikte öğretmenlerin çocuklara mekân ve yön kavramıyla ilgili olarak öğretmeye çalıştıkları kazanımların daha çok çocukların motor gelişimlerine yönelik becerilerden oluştuğu görülmektedir. Okul öncesi öğretmenlerinin çocuklara mekân ve yön kavramını öğretirken daha çok temelinde hareket olan becerilere yer verdiğini söylemek mümkündür. Foley ve Janikoun'a (1996) göre hareket etkinlikleri, oyun etkinlikleri, drama etkinlikleri ve alan gezileri çocuklarda yön becerisi geliştirilebilir. Ayrıca çocukların, "sağ-sol, sağında solunda, yukarı-aşağı, yukarıda-aşağıda, ilerigeri” gibi yöne ilişkin kavramları eğlenerek öğrenmelerinde oyunlar önemli rol oynar (Coşkun Keskin \& Daysal, 2015).

Okul öncesi eğitim döneminde öğretmenlerin çocuklara mekân ve yön kavramını öğretirken kazandırmaya çalıştıkları becerilerin içerisinde genellikle; yönergede yer alan hareket çalışmaları yaptırdıkları $(\%$ 36,66), nesneleri konumlarına göre yerleştirme çalışmaları yaptırdıkları (\% 20), mekânda konum çalışmaları yaptırdıkları $(\%$ 13,33), bir nesnenin bulunduğu konumu söyleme çalışmaları yaptırdıkları (\% $13,33)$ ve yön kavramını öğretmeye çalıştıklarını (\% 13,33) ifade etmişlerdir. Elde edilen bu verilerden hareketle okul öncesi öğretmenlerinin çocuklara mekân ve yön kavramını öğretirken onların hazırbulunuşluk seviyelerine ve gelişim düzeylerine uygun etkinliklere yer verdiklerini söylemek mümkündür.

Okul öncesi eğitim döneminde öğretmenlerinin çocuklara mekân ve yön kavramını öğretirken kullandıkları yöntem, teknik, uygulama ve etkinliklerin genellikle; gösterip yaptırma öğretim yöntem ve tekniği ile (\% 22,91) oyun etkinlikleri (\% 45,61) olduğunu; sonrasında drama öğretim yöntem ve tekniği ile (\% 20,83), okuma yazma etkinliklerini kullandıklarını ( \% 17,54); daha sonra öğrenme 
sürecinde soru cevap öğretim yöntem ve tekniğini (\% 14,58), kavram kartları etkinliklerine yer verdiklerini $(\% 7,01)$; bununla birlikte bu süreçte anlatım öğretim yöntem ve tekniği ile (\% 10,41), hikayeleştirerek öğretme etkinliklerini tercih ettiklerini $(\% 5,26)$; zaman zamanda yaparak ve yaşayarak öğretme yöntemini (\% $8,33)$, komut (yönlendirme) etkinliklerini kullandıklarını $(\% 5,26)$ ifade etmişılerdir. $\mathrm{Bu}$ sonuçlarla ilgili olarak, gösterip yaptırma yönteminde çocukların uygulamaya dayalı duyuşsal becerilerinin yanı sıra motor becerilerinin desteklenmesinde oldukça önemlidir (Sönmez, 2011). Görüldüğü gibi okul öncesi eğitim döneminde öğretmenlerin çocuklara mekân ve yön kavramını öğretirken çoğunlukla görsel ve işitsel öğelerin bir arada kullanıldığı gösterip yaptırma öğretim yöntem ve tekniğini kullandıkları tespit edilmiştir. Bu yöntem ve tekniği kullanırken de öğretmenlerin çoğunlukla çocukların içinde bulundukları yaş ve gelişim düzeyleri açısından en çok ilgilerini çeken oyun etkinliklerine yer verdikleri belirlenmiştir. Okul öncesi eğitimde oyun ise, çocuğun yaratıcı potansiyelini kullanabildiği, yeteneklerini keşfettiği, kendini ifade ettiği ve gelişimsel özellikleri hakkında yetişkine ipuçları verdiği önemli bir araçtır (Kaya, Yalçın, Kimzan \& Avar, 2017). Ayrıca çocukların öğrenme ve öğretme sürecinde motivasyonlarını artıracak, ilgilerini çekecek ve meraklarını uyandıracak drama, soru cevap, anlatım, yaparak ve yaşayarak öğrenme gibi öğretim yöntem ve tekniklerini kullandıkları tespit edilmiştir. Okul öncesi dönem çocukları için drama; farklı bakış açıları geliştirme, empati becerileri kazandırma ve sosyal gelişimlerini destekleme de oldukça önemli bir etkiye sahiptir (Ülker Erdem, Aydos \& Gönen, 2017). Elde edilen bu verilerden yola çıkarak okul öncesi eğitim döneminde öğretmenlerin çocuklara mekân ve yön kavramları öğretirken onların çok sayıda duyu organına hitap edecek yöntem ve tekniklere yer verdikleri, öğrenme sürecini daha açık ve anlaşılır hale getirecek etkinlikler kullandıklarını söylemek mümkündür. Bununla birlikte öğretmenlerin bu süreçte kullandıkları öğretim yöntem ve tekniklerle, bu yöntemleri kullanırken uyguladıkları etkinliklerin genellikle çocukları aktif öğrenmeye teşvik eden öğrenci merkezli etkinlikler olduğu söylenilebilir.

Okul öncesi eğitim döneminde öğretmenlerin çocuklara mekân alg1sı ve yeryönlerle ilgili öğretiminde zorluk yaşanan kavramlar sırasıyla; sağ ve sol kavramlarını $(\% 76,92)$, ortasında ve arasında kavramlarını (\% 7,69), derin ve sağ kavramlarını (\% $3,84)$ ve sıralama kavramları $(\% 3,84)$ olduğunu belirtmişlerdir. Ayrıca öğretmenlerin bir kısmı mekân ve yönle ilgili herhangi bir kavramı öğretmede zorlanmadıklarını (\% 7,69) da dile getirmişlerdir. Okul öncesi eğitim döneminde öğretmenler çocuklara mekân ve yer-yön ile ilgili kavramları öğretirken zorlanma nedenleri olarak sırasıyla; bazı kavramların soyut oluşunu (\% 50), bazı kavramların günlük hayatta daha az kullanılmasını (\% 7,69), çocukların yaşlarının küçük olmasını, kavram kargaşası ve bazı kavramların anlaşılmasının zor olmasını $(\%$ 3,84) ifade etmişlerdir. Bununla birlikte öğretmenlerin (\% 30,76) mekân ve yer-yönle ilgili kavramları çocuklara öğretmede herhangi bir nedenden dolayı zorlanmadıklarını ifade etmişılerdir. Araştırmadan elde edilen bu verilerden hareketle okul öncesi öğretmenlerin çocuklara mekân ve yön kavramını öğretirken öğretme sürecini soyuttan somuta çevirecek çeşitli öğretim materyalleri daha yoğun olarak kullanması gerektiğini söylemek 
mümkündür. Ayrıca öğretmenlerin mekân ve yön kavramını çocuklara öğretirken onların içinde bulundukları yaş ve gelişim özeliklerini dikkate alarak yapacağı etkinlikler, öğrenme sürecini daha somut hale getirebilir. Bu araştırma sonucunu destekleyen benzer bir araştırmada Davis ve Hyun (2005), yaptıkları olgu bilim çalışmasında anasınıfına devam eden 18 çocuğun mekânsal temsil becerilerini incelemişlerdir. Bir yıl süren bu çalışmada, iki farklı sınıf ortamında, farklı öğretim yöntem ve materyalleri kullanılmıştır. Eğitimler, normal okul öncesi eğitim sınıfı ile teknoloji açısından zenginleştirilmiş sınıfta gerçekleştirilmiştir. Öğrenme sürecini zenginleştirmek ve daha somut hale getirmek için kullandıkları teknolojik materyallerin etkinliklere katılan çocukların mekânsal temsil becerilerini olumlu yönde geliştirdiği sonucuna ulaşmışlardır.

Katılımcıların, çocuklara öğretiminde zorluk yaşadıkları mekan kavramı ve yön becerileriyle ilgili olarak ileri sürdükleri çözüm önerileri sırasıyla; bireylerin gelişim özelliklerine göre kavramları somutlaştırmak gerektiği (\% 18,91), kavramları sürekli hatılatacak etkinlikler yaptırılmasını (\% 18,91), aile ve ev ortamında pekiştirici etkinlikler yapılmasını, oyunlara daha fazla yer verilmesi gerektiğini, etkinlikleri çeşitlendirmek ve günlük yaşamla ilişkilendirmek gerektiğini, robotik kodlama ve stem etkinlikleri yaptırılabileceğini $(\%$ 8,10) ifade etmişlerdir. Görüldüğü gibi okul öncesi eğitim döneminde öğretmenlerin çocuklara mekân ve yön kavramı öğretirken onların günlük hayatta işine yarayacak işlevsel bilgiler vermesi, öğrenme sürecini günlük yaşamdan örnekler vererek zenginleştirmesi öğrenmeyi daha kolay ve anlaşılabilir hale getirebilir.

Araştırmadan elde edilen sonuçlar doğrultusunda aşağıdaki öneriler getirilebilir.

- Okul öncesi öğretmenliğinin sadece bayanların yaptığı bir meslek olmadığına yönelik toplumda farkındalık yaratacak bilimsel çalışmalar yapilabilir.

- Çocuklara öğretim programlarında, mekân ve yön kavramıyla ilgili kazanımlar verilirken onlara motor beceriye dayalı gösterip yaptırma, oyun ve drama etkinliklerine sıklıkla yer verilmesi konuyla ilgili öğrenmelerin niteliğini arttırabilir.

- Okul öncesi öğretmenleri mekân ve yön kavramını çocuklara öğretirken onların gelişim düzeylerini ve yaşlarını dikkate alarak soyut öğrenmeleri somut hale getirecek öğretim materyal ve teknolojilerini sınıf ortamına taşımayı öncelikli amaçları haline getirebilir.

- Okul öncesi eğitim döneminde mekân ve yön algısı kazandırılmaya çalışırken aktif öğrenme yönteminin kullanılabileceği tespit edilmiştir. $\mathrm{Bu}$ kapsamda okul öncesi öğretmenlerinin aktif öğrenme yöntemini eğitim ortamında nasıl kullanabileceklerine ilişkin öğretmenlere hizmet içi eğitim kursları verilebilir.

- Okul öncesi eğitimde çocuklara mekân ve yön kavramları öğretilirken öğretmenlerin çocukların günlük yaşamdan örnekler vererek açıklamaları ve 
konuyla ilgili işlevsel bilgiler vermesi öğrenme sürecini daha anlaşılır ve eğlenceli hale getirebilir.

\section{Çıkar Çatışması ve Etik Bildirimi}

Yazarlar arasında çıkar çatışması bulunmadığını ve tüm araştırmacıların çalışmaya eşit oranda katkı sunduğunu beyan etmiştir. Yazarlar tüm etik kurallara uyduklarını bildirmiştir.

\section{Kaynakça}

Akgün, Ü. E. (2011). Müzelerde mekân kurgusunun algı ve yön bulmadaki etkisinin incelenmesi (Tez No. 328136) [Yüksek lisans tezi, İstanbul Teknik Üniversitesi-İstanbul]. Yükseköğretim Kurulu Başkanlığı Tez Merkezi.

Akkuş, D. (2019). Üniversitelere yerleşen üstün başarılı ögrencilerin erken çocukluk yaşantılarının incelenmesi (Tez No. 581068) [Yüksek lisans tezi, Aydın Üniversitesiİstanbul]. Yükseköğretim Kurulu Başkanlığı Tez Merkezi.

Anıktar, S. (2008). Çocukların mekân algısının gelişiminde bilgisayarın etkisinin araştııılması. (Tez No. 237143) [Yüksek lisans tezi, Yıldız Teknik Üniversitesi-İstanbul]. Yükseköğretim Kurulu Başkanlığı Tez Merkezi.

Aslan, B., İ. (2017). Çocuk gelişimi-spor ilişkisinin fiziksel çevre ve mekân algısı üzerinden irdelenmesi: örnek bir hareket merkezi modeli. (Tez No. 467905) [Doktora tezi, Mimar Sinan Güzel Sanatlar Üniversitesi-İstanbul]. Yükseköğretim Kurulu Başkanlığı Tez Merkezi.

Aydınözü, D., Demirbaş, İ., \& Demir, B. D. (2019). Classroom teachers' opinions on gaining gains related to direction and direction finding in primary school students. International Journal of Geography and Geography Education (IGGE), 41, 59-72.

Ayvaz, A. (2007). Çocukların sanal ortamlarda nasıl mekanlar tasarladıklarının araşstırılması. (Tez No. 222122) [Yüksek lisans tezi, Gazi Üniversitesi-Ankara]. Yükseköğretim Kurulu Başkanlığı Tez Merkezi.

Blades, M., Sowden, S., \& Spencer, C. (1996). Young children's use of spatial relations in tasks with maps and models. Cartographica, 32, 18-29.

Brinkmann, S. (2013). Qualitative interviewing: Understanding qualitative research. New York: Oxford University Press.

Creswell, J. W. (2016). Nitel araştırma yöntemleri: Beş yaklaşıma göre nitel araştırma ve araştırma deseni. (Çev. Edt: M. Bütün \& S. B. Demir). Siyasal Kitabevi.

Creswell, J. W. (2017). Araştırma deseni, nitel nicel ve karma yöntem yaklaşımları (Çev. Edt: S. B. Demir). Eğiten Kitap Yayıncılık. 
Coşkun Keskin, S., \& Daysal, D.(2015). İnsanlar, mekânlar ve çevreler: Coğrafya. S. Coşkun Keskin (Çev. Ed.). Okul öncesi/ilkokul çocukları için sosyal bilgiler öğretimi, (9. basımdan çeviri, s. 238-275) içinde. Nobel Yayıncılık.

Çakıroğlu, N. (2013). Ebeveynlerin okul öncesi eğitim ile ilgili görüşleri ve bu eğitimden beklentileri (Devrek İlçesi Örneği) (Tez No. 330265) [Yüksek lisans tezi, Gazi ÜniversitesiAnkara]. Yükseköğretim Kurulu Başkanlığı Tez Merkezi.

Davis, G.A., \& Hyun, E. (2005). A study of kindergarten children's spatial representation in a mapping project. Mathematics Education Research Journal, 17(1), 73-100.

Demirci, A. (2019). Plastik sanatlarında mekan algısı. (Tez No. 555883) [Yüksek lisans tezi, Hacettepe Üniversitesi-Ankara]. Yükseköğretim Kurulu Başkanlığı Tez Merkezi.

Demirkaya, H., Çetin, T., \& Tokcan, H. (2004). İlköğretim birinci kademe öğrencilerine yön kavramı öğretiminde kullanılabilecek metotlar. Gazi Üniversitesi Gazi Eğitim Fakültesi Dergisi, 24(3), 39-70.

Foley, M., \& Janikoun, J. (1996). The really practical guide to primary geography. (Second Edition). Stanley Thornes (Publishers) Ltd.

Hasgül, E. (2011). İ̧̧ mekanda yön bulma: büyük ölçekli binalarda inceleme (Tez No. 286611) [Yüksek lisans tezi, İstanbul Teknik Üniversitesi-İstanbul]. Yükseköğretim Kurulu Başkanlığı Tez Merkezi.

Huttenlocker,J., Newcombe, N.S., \& Vasilyeva, M. (1999). Spatial scaling in young children. Psychological Science, 10, 393-398.

İncekara, B. (2018). Çocukların mekan algısı ve katılımcı tasarım yöntemlerinde rolü: muş ve harran yerleşimleri (Tez No. 512051) [Yüksek lisans tezi, İstanbul Teknik Üniversitesiİstanbul]. Yükseköğretim Kurulu Başkanlığı Tez Merkezi.

Erbil Kaya, Ö. M., Kimzan, İ., Yalçın, V., \& Avar, G. (2017). Okul öncesi öğretmeni adaylarının oyun temelli öğrenmeye bakış açıları ve uygulamaya yansımaları. Adıyaman Üniversitesi Sosyal Bilimler Enstitüsü Dergisi. 27, 800-834.

K1lıç, Z. (2008). İlköğretim birinci sınıf ögrretmenlerinin görüşlerine göre okul öncesi eğitim alan ve almayan öğrencilerin gelişim becerilerinin karşılaştırılması (Tez No. 235388) [Yüksek lisans tezi, Beykent Üniversitesi-Ankara]. Yükseköğretim Kurulu Başkanlığ1 Tez Merkezi.

Koç, B. (2012). Çocuklar için tasarlanan mekânlarda bilişsel sınırlar (Tez No. 323794) [Yüksek lisans tezi, İstanbul Teknik Üniversitesi-İstanbul]. Yükseköğretim Kurulu Başkanlığı Tez Merkezi.

Kurt, Ö. (2016). İlkokul mekânlarının çocuk gelişimi ve mekân algısına etkilerinin değerlendirilmesi (Tez No. 432425) [Yüksek lisans tezi, Anadolu Üniversitesi-Eskişehir]. Yükseköğretim Kurulu Başkanlığı Tez Merkezi. 
Kuzey, M., \& Değirmenci, Y. (2019). Sosyal bilgiler öğretmen adaylarının harita ve yön okuryazarlığına ilişkin kavramları anlama düzeyleri ve kavram yanılgıları. Milli Eğitim Dergisi, 48(223), 207-230.

McMillan, J.H. (2015). Fundamentals of educational research (7. Ed.). Pearson, İnc.

MEB (2013). Okul Öncesi Eğitim Programı https://tegm.meb.gov.tr/. 10.02.2020 Erişim Tarihi.

Merriam S. B. (2013). Nitel araştırma desen ve uygulama için bir rehber (Çev. Edt: S. Turan). Nobel Yayınları.

Miles, M. B., \& Huberman, M. A. (1994). An expanded sourcebook qualitative data analysis. London: Sage.

Öztürk, E. B. (2019). Okul öncesi gelişiminde sanat eğitimin yeri ve önemi (Tez No. 590185) [Yüksek lisans tezi, Trabzon Üniversitesi-Trabzon]. Yükseköğretim Kurulu Başkanlığı Ulusal Tez Merkezi.

Öztürk, M., Giren, S., Yıldırım, E., \& Şimşek, Ü. (2015). Güncellenen Okul Öncesi Eğitim Programının Coğrafya Eğitimi Açısından İncelenmesi. Celal Bayar Celal Bayar Üniversitesi Sosyal Bilimler Dergisi, 13(4), 245-262.

Patton, M.Q. (2002). Qualitative research and evaluation methods (3rd ed.). London: Sage Publications, Inc.

Plester, B., Richard, J., Blades, M., \& Spencer, C. (2002). Young children's ability to use aerial photographs as maps. Journal of Environmental Psychology, 22, 29-47.

Selçuk, Z. (2005). Gelişim ve Öğrenme. (12. Bask1). Nobel yayınları.

Soydan, S. (2014). Türkiye, Amerika ve Avusturya'da görev yapan öğretmenlerin okul öncesi coğrafya öğretimi ile ilgili görüşlerinin incelenmesi. Dumlupınar Üniversitesi Sosyal Bilimler Dergisi. 40, 9-31.

Sönmez, S. (2011). Yaratıcı drama yöntemiyle bir oyun metninin Brecht dramaturgisine göre incelemesi. (Bitirme Projesi). Ankara, Çağdaş Drama Derneği.

Şahin, N. E. A. (2019). Çocuklarda mekan algısı ve mekansal imge zenginliği bakımından tasarımın önemi (Tez No. 562005) [Yüksek lisans tezi, Mimar Sinan Güzel Sanatlar Üniversitesi-İstanbul]. Yükseköğretim Kurulu Başkanlığı Tez Merkezi.

Şahin, M. K., Çoban, A. E., \& Korkmaz, A. (2016). Toplumsal cinsiyet eşitliği ve Türk eğitim sistemindeki yeri: okul öncesi öğretmen adaylarının gözünden. Uluslararası Bilimsel Araştırmalar Dergisi (IBAD), 3 (2), 735-752.

TDK (2011). Türkçe Sözlük. Türk Dil Kurumu Yayınları.

Uçan, S. (2019). Durum çalışması araştırması. S. Şen \& İ. Yıldırım (Ed.) Eğitimde araştırma yöntemleri (s. 227-248) içinde. Nobel Akademik Yayıncılık. 
Uçar, Ö. (2013). Çocukların yaşanılan yer ve buna bağlı olarak mekan algısının incelenmesi (yüksek konut yapıları örneği) (Tez No. 373958) [Yüksek lisans tezi, Dokuz Eylül Üniversitesi-İzmir]. Yükseköğretim Kurulu Başkanlığı Tez Merkezi.

Ülker Erdem, A., Aydos, E., \& Gönen, M. (2017). Okul öncesi eğitim ortamlarında yaratıcı drama kullanımı: öğretmenler ve öğretmen adayları perspektifinden bir inceleme. Hasan Ali Yücel Eğitim Fakültesi Dergisi, 14 (1), 409-424.

Yağbasan, M., \& Aksoy, G. P. (2016). Erkek anaokulu öğretmenlerine velilerin bakış açısı (Elazı̆̆ İli Özelinde Bir Alan Araştırması). Turkish Journal of Educational Studies, 3(3), 85-113.

Yaylacı, Z., \& Aksoy, B. (2017). Zihinsel yetersizliğe sahip öğrencilere yön bulma becerisinin kazandırılması. Anadolu Kültürel Araştırmalar Dergisi, 1(1), 35-50.

Yıldırım, A., \& Şimşek, H. (2011). Sosyal Bilimlerde Nitel Araştırma Yöntemleri (8. Baskı). Seçkin yayıncılık.

Yin, R. K. (2018). Case study research and applications design and methods (Vol. 6). Sage Publications.

\section{Extended Abstract}

Preschool period covers the first six years of the child and refers to a process in which the child's lifelong development is constructed. In the period when brain development and the rate of establishing synaptic connections are most intense and fast, a strong ground is created for the child's cognitive, motor and affective development. Effective and permanent education takes place between the ages of 0-6. This age period is the most productive years of the child. In other words, it is a critical process in preparing the child for life and developing basic skills. In this process, if the learning that is necessary for the individual is not realized, these learnings will be more difficult in other periods of life. Since the quality of education taken in preschool period is so important, the location and direction information should be given in this period. As a matter of fact, when the preschool education program and the activity book are examined for this purpose, it is seen that the place and direction education is included in the preschool program.

In the program and activity book; it is included gains and activities for cognitive development regarding the concepts of space and direction about 48-60 month-old children. In this period, in relation to the cognitive development process, there are also studies to apply the directions on location in the space. Within the scope of this directive, it works to tell the position of the object in the space and to place the objects in the desired place within the scope of the directive. Within the scope of the directive on location in the space, acquisition studies for the use of map and sketch are included. When the related literature is analyzed, it is seen that there are various studies about space perception and direction concepts but the studies related to the concepts of space 
perception and location and direction skills are given to individuals in preschool period, and studies on how these concepts are brought to children are limited. Therefore, by taking the opinions of teachers from the field, it is expected that how these concepts and skills are acquired to children, what methods, techniques, practices or activities are used, the difficulties experienced in the process and what the solution suggestions of the participants, if any, constitute the most important dimension of this research and will contribute to the relevant literature. In this study, where the opinions of the teachers working in the preschool period regarding the space perceptions and direction skills of the preschool students are examined, case study, which is one of qualitative approaches was used. Qualitative research is the research in which perceptions and multiple real life events are tried to be presented with a realistic and holistic perspective within natural environments. The study was conducted with 26 pre-school teachers who are currently working in the 2019-2020 academic year and they were selected in accordance with the match sampling method. In the research, according to the opinions of preschool teachers with different teaching experience, what are the perceptions and direction skills of individuals in preschool period, what concepts or skills are acquired for them, what kind of methods, techniques or practices are used in gaining these skills, the difficulty in teaching perception of space and directions. Opinions and thoughts about the concepts experienced, and finally what the solution suggestions may be, were examined using the interview technique commonly used in qualitative research.

It is imperative that the individual perceives the space in which he lives from the moment he first opens his eyes to life and acts within the perception of the space. Preschool education period, which is considered as the most critical and most important period of child development, is the first step of the formal education process in which the child is directed to grasp the direction of the surrounding objects according to the position of his own body, and where some acquisition activities are carried out for the development of the concept of spatial perception in the child.

This research was carried out together with preschool teachers who tried to bring the space perception and direction skills of preschool students to children from a young age. In this context, questions were asked to the preschool teachers in the study group about what kind of studies they carried out to increase the awareness of children about the concept of space and direction. Based on the answers given by preschool teachers to these questions, the following results were obtained. According to the findings obtained in the research. It has been observed that preschool teachers provide students with a variety of concepts and skills for their perception of space and direction skills. In the meantime they use different methods, techniques, practices and activities. But they have difficulties in teaching some concepts and finally they offer some solutions for them. 